\title{
User Role Context
}

National Cancer Institute

\section{Source}

National Cancer Institute. User Role Context. NCI Thesaurus. Code C63535.

A class which hold the roles which are assumed by a particular group in the context of a protection group. 